\title{
Comparison of the prevalence rates of metabolic disorders between two groups of women undergone surgically induced menopause by hysterectomy and bilateral oophorectomy: A population-based study
}

Maryam Farahmand ${ }^{1}$, Fahimeh Ramezani Tehrani ${ }^{2}$, Fereidoun Azizi ${ }^{3}$

1. PhD, Reproductive Endocrinology Research Center, Research Institute for Endocrine Sciences, Shahid Beheshti University of Medical Sciences, Tehran, Iran. ORCID ID: 0000-0002-1748-5687

2. Professor, Reproductive Endocrinology Research Center, Research Institute for Endocrine Sciences, Shahid Beheshti University of Medical Sciences, Tehran, Iran. Tel: 021-22432500, Email:ramezani@endocrine.ac.ir. ORCID ID: 0000-00024609-065X

3. Professor, Endocrine Research Center, Research Institute for Endocrine Sciences, Shahid Beheshti University of Medical Sciences, Tehran, Iran. ORCID ID: 0000-0002-6470-2517

\section{ABSTRACT}

Background and Aim: Surgically induced menopause after bilateral oophorectomy, leads to a sudden drop in the secretion of sex hormones from the ovaries. Hysterectomy is another surgical procedure that leads to menopause, without an abrupt drop in the secretion of sex hormones. The aim of this study was to compare the prevalence rates of metabolic disorders between hysterectomized and oophorectomized women.

Materials and Methods: This cross-sectional study included postmenopausal women participating in Tehran Lipid and Glucose Study. Initially, 549 surgically induced postmenopausal women (age range of 20-70 years) entered the study. Then, all the subjects with menopausal age of 50 years or older were excluded. Data were extracted from Tehran Lipid and Glucose Study Questionnaires.

Results: The mean age of the participants and age at menopause were $60.8 \pm 9.8$ and 43.7 \pm 4.6 years, respectively. The prevalence rate of the metabolic syndrome in the postmenopausal women who had undergone bilateral oophorectomy $(71.3 \%)$ was higher than that in the hysterectomized women $(66.5 \%)$, but this difference was not significant. Prevalence of pre-hypertension was higher in the oophorectomized women after adjusting for confounding variables $(31.7 \%$ vs. $23.0 \%, P=0.01)$.

Conclusion: Our findings showed the prevalence rate of pre-hypertension was higher in oophorectomized women. Therefore, screening measures for the prevention of this disorder in these women are necessary.

Keywords: Noncommunicable disease, Menopause, Surgical menopause, Metabolic syndrome, Metabolic disorders

Received: Dec 1, $2019 \quad$ Accepted: Mar 10, 2020

How to cite the article: Maryam Farahmand, Fahimeh Ramezani Tehrani, Fereidoun Azizi. Comparison of the prevalence rates of metabolic disorders between two groups of women undergone surgically induced menopause by hysterectomy and bilateral oophorectomy: A population-based study. SJKU 2021;25(6):79-89.

Copyright (C 2018 the Author (s). Published by Kurdistan University of Medical Sciences. This is an open access article distributed under the terms of the Creative Commons Attribution Non-Commercial License 4.0 (CCBYNC), where it is permissible to download, share, remix, transform, and buildup the work provided it is properly cited. The work cannot be used commercially without permission from the journal 


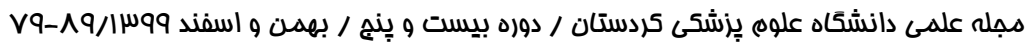

\section{مقايسه شيوع اختلالات متابوليك در زنان يائسه به علت هيستر كتومى با زنان يائسه به علت اووفور كتومى دو طرفه: يك مطالعه مبتنى بر جمعيت}

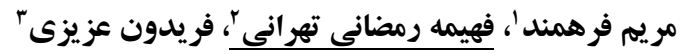

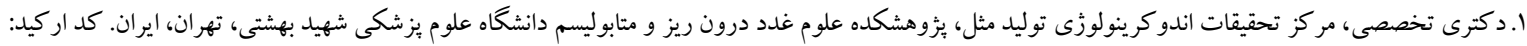
$\Delta 9 \Lambda V-I V Y A-\cdots Y-\cdots$

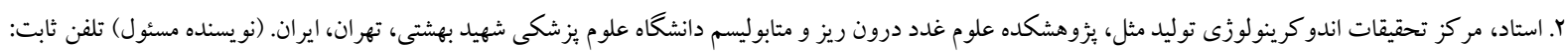

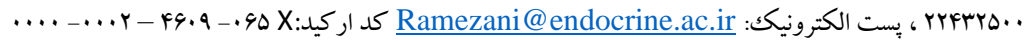

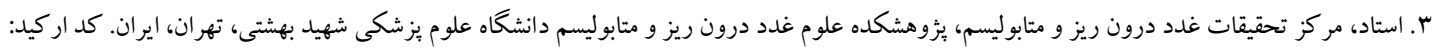
$\cdots \cdot \cdots \cdot r-g Y V \cdot-r \Delta I V$

زمينه و هدف: متعاقب يائسخى جر احى به روش اووفور كتومى دوطرفه، قطع ناگهانى هورمون هاى جنسى اتفاق مى افتد. از سوى

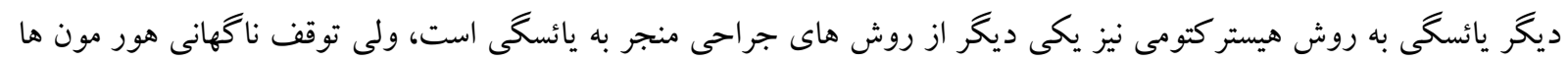

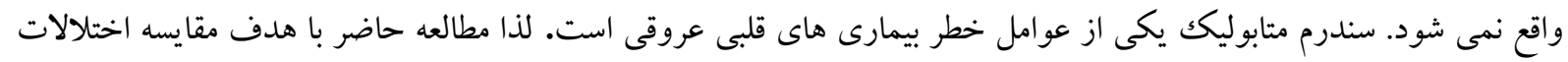
متابوليك در دو گروه يائسه فوق انجام شد. مواد و روش ها: اين مطالعه بر روى زنان مشاركت كننده در طرح قند و ليييد تهران انجام شد. ابتدا هوه ئه زن يائسه به روش

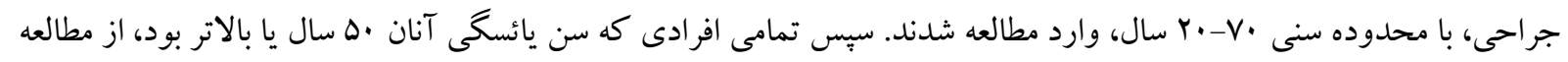

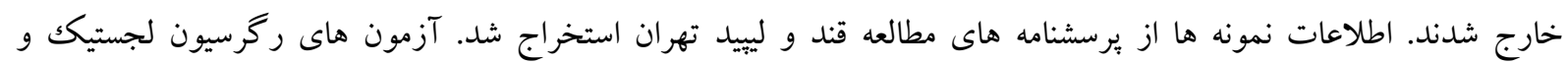
آناليز كوواريانس استفاده شد.

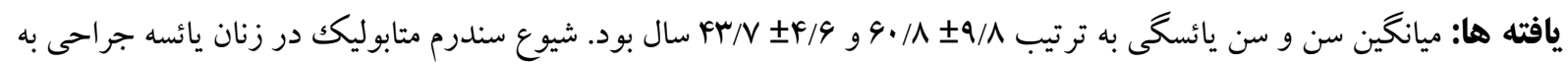

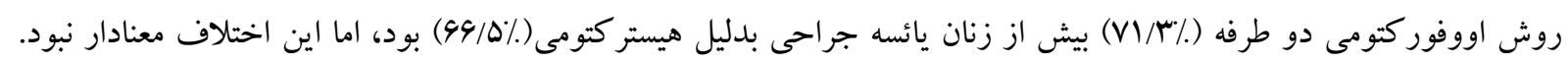

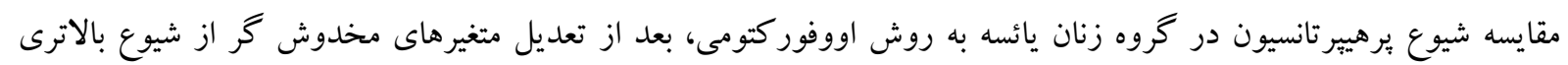

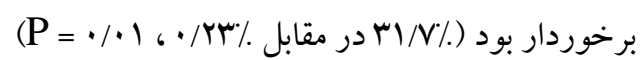
نتيجه كيرى: زنان يائسه بدليل اووفوركتومى دوطرفه در مقايسه با زنان يائسه به روش هيستر كتومى، بيشتر در معرض خطر

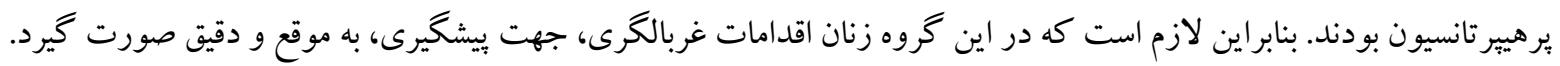

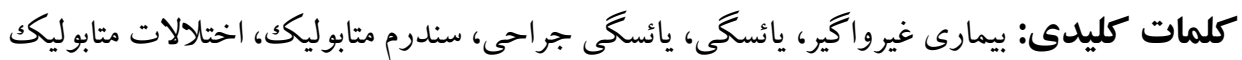

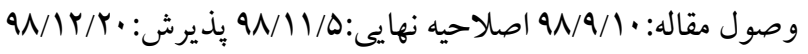


ويزه در سياست كذارى هاى كلان بهداشتى جوامع مورد

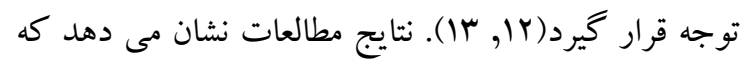
كمبود استروزن داخلى، از نظر طول دوره در معرض قرار كرفتن يا مقدار آن، با بيامدها و بيمارى هاى قلبى عروقى (كه سندرم متابوليك يكى از ريسك فاكتورهاى آن است) ارتباط دارد(f أ|19). از آنجا كه طبق مطالعات قبلى بدنبال يائسگى جراحى خطر بعضى از فاكتورهاى مؤثر بر بيمارى هاى قلبى عروقى افزايش مى يابد و اين افزايش عوامل خطر به نظر مى رسد كه عمدتابر اساس نقش كليدى استروزن در اين زمينه باشد، ولى هنوز مشخص نيست كه آيا اين دو

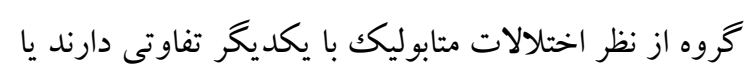
خير. لذا در اين مطالعه به بررسى و مقايسه اختلالات متابوليك بدنبال يائسخى جراحى با برداشتن هر دو تخمدان

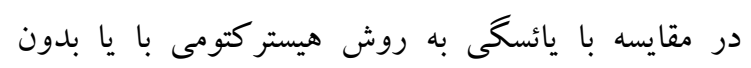

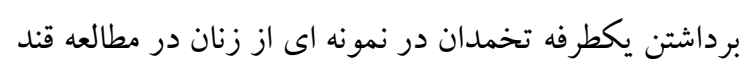

$$
\text { و ليبيد تهر ان برداختيم. }
$$

\section{مواد و روش ها}

در اين مطالعه همخروهى، نمونه هاى يزٔوهش راز رازنان يائسه مطالعه قند و ليييد تهران كه در محدوده سنى .Y-Y.V سال

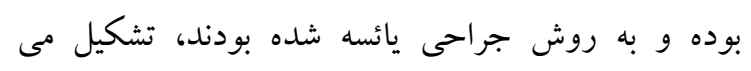

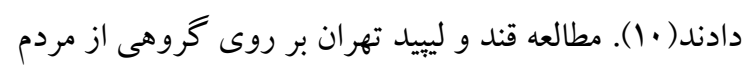
تهران در منطقه سا طراحى شده و بررسى عوامل مرتبط با بيمارى هاى غير واگير ماند بيمارى هاى قلبى عروقى از اهداف آن است. بدين منظور تعداد هوه از زنان يائسه در ابتدا وارد مطالعه شدند. شايان ذكر است كه در مطالعه قند و ليبيد تهران، نمونه ها مورد بررسى قرار كرفته و اطلاعات

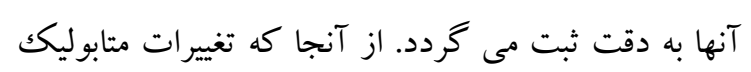
تابع سن هستند و سن بالاى •ه سال طبق مطالعات از هدف بررسى تغييرات بدنبال يائسگى جراحى خارج شده و وجود اين افراد مى تواند نتايج را مخدوش نمايد لذا تمامى نمونه هايى كه سن يائسخى آنها •ه سال يا بيشتر بود از مطالعه
مقدمه

بدنبال فرسايش مخزن فوليكول هاى تخمدان يائسكى ايجاد مى شود، كه خود متعاقب كاهش تدريجى يا ناخهانى هورمون هاى جنسى بوقوع مى بيوندد (1)، لذا علائمى از

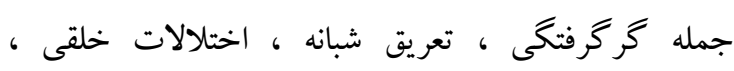
اختلالات خواب، اختلالات ادرارى ، كاهش حجم استخوان و اختلالات متابوليكك متعاقب كاهش بارز هورمون

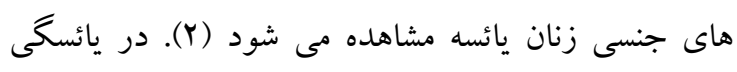
جراحى به روش اووفوركتومى دوطرفه، قطع ناخهانى هورمون هاى جنسى اتفاق مى افتد، لذا به نظر مى رسد كه

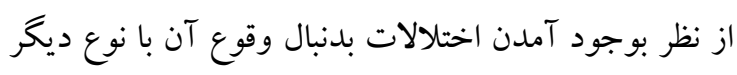
يائسكى جراحى كه هيستر كتومى است، متفاوت باشد. سندرم متابوليكك در ابتدا توسط رون در سال 1911 به عنوان سندرم مقاومت به انسولين يا سندرم ايكس شناخته شد. اين سندرم يكى از ريسك فاكتورهاى مهم بيمارى هاى غيرواگيرمانند بيمارى هاى قلبى عروقى و ديابت تيب محسوب مى شود(r). مطالعات نشان مى دهند كه شيوع

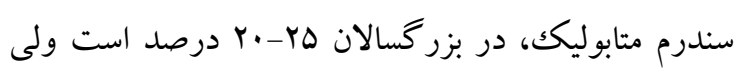
اين شيوع در زنان يائسه حدود Y برابر بيشتر تخمين زده شده

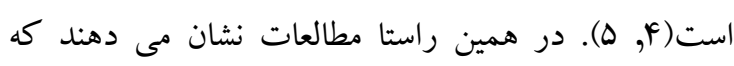
شيوع اختلالات متابوليك در زنان غير يائسه، نسبت به مردان شيوع كمترى دارد، ولى بدنبال يائسكى افزايش مى يابد (9). علاوه بر آن علت به وجود آمدن يائسگى در شيوع اختلالات متابوليك دخيل است و مطالعات حاكى از آن هستند كه زنانى كه به روش جراحى يائسه مى شوند، بيشتر در معرض خطر اختلالات متابوليك هستند، به ويزه افرادى هي كه جراحى در آنها منجر به از دست دادن تخمدان ها شده است كه اين خود باعث تحت تأثير قرار كرفتن كيفيت زندكى اين كروه از زنان مى شود(V-V) (I). اين نكته نيز حائز اهميت است كه اميد به زندگى در جوامع بشرى افزايش

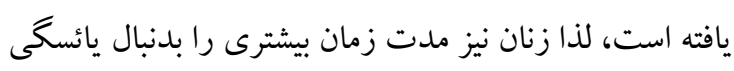
سبرى خواهند كرد، بنابراين توجه به حفظ و ارتقا كيفيت زندكى و سلامت دوران يائسخى از نكاتى است كه بايد به 
خون بالا (ير هيبرتانسيون) بر اساس ميزان فشار خون

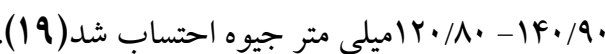
متغيرهاى يُزوهش شامل شاخص هاى تن سنجى ، تاريخجه بارورى و فاكتورهاى بيوشيميايى خون بودند. قد نمونه هاى

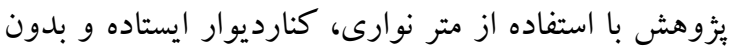
كفش، با دقت يكك سانتى متر اندازه گيرى شده و نمونه ها با باري

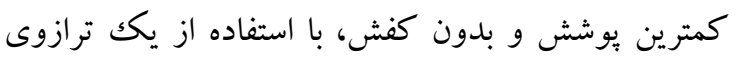

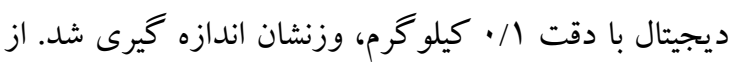
تقسيم وزن به كيلو گرم بر قد به متر مربع نمايه توده بدن

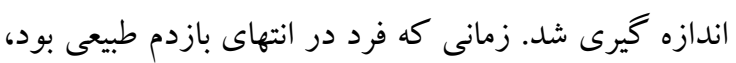

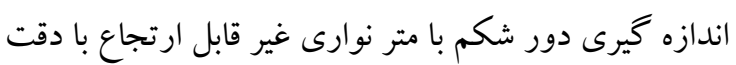

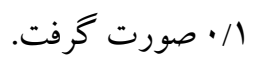

از تمامى نمونه هاى يزوهش بدنبال يك دوره ناشتايى شبانه

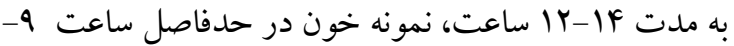

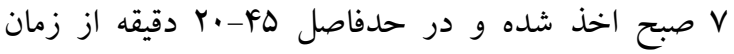

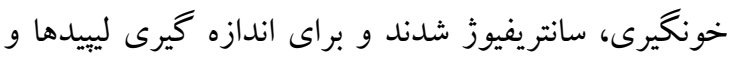
لييويروتئين هاى سرم مورد استفاده قرار خرفت. جهت تعيين گروه مرجع، تمامى نمونه هاى اين يُزوهش كه مهرد فقط هيستركتومى كرده اند با يا بدون برداشتن يكطرفه تهن

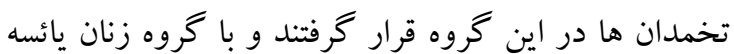
بدليل برداشتن دوطرفه تخمدان ها مقايسه شدند.

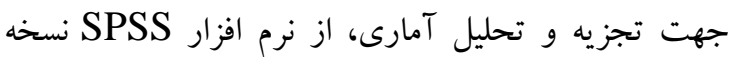

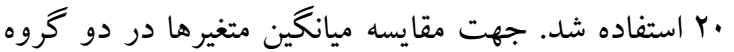
مطالعه از آزمون تى و از آزمون مجذور خى جهت مقايسه

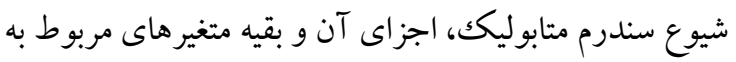

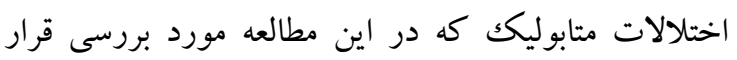

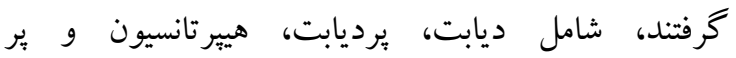

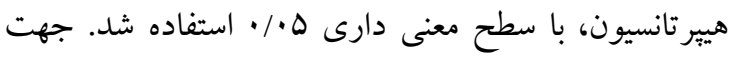

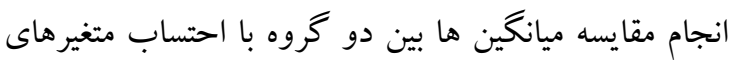

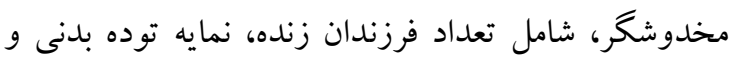

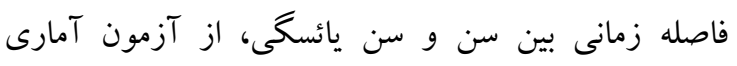

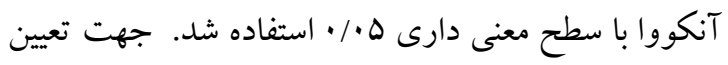
شيوع سندرم متابوليكك و اجزا آن، به همراه تعيين شيوع بقيه

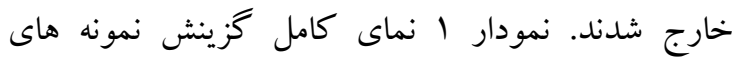
يُو هُش را نشان مى دهد. بمنظور جمع آورى داده ها از اطلاعات برسشنامه هاى رهاى

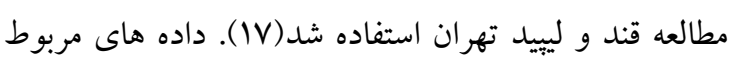
به زنان يائسه به روش جراحى در دو گروه زينان يائسه، شامل

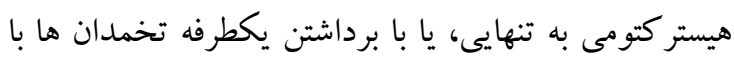

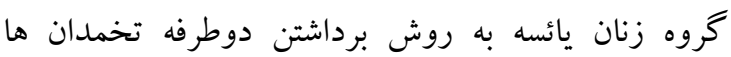

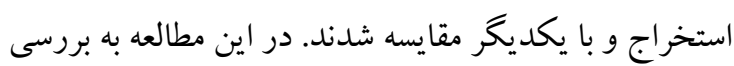

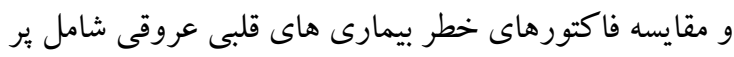
ديابت و يرهييرتانسيون، همجنين ديابت و هييرتانسيون، سندرم متابوليكك و اجزاى آن در مقايسه اين دو گروه زئنان يائسه جراحى يرداخته شد. جهت تشخيص سندرم متابوليك، از مطالعات قبلى استفاده شده و بر اين اساس دور كمر بيشتر يا برابر با هو سانتى متر،

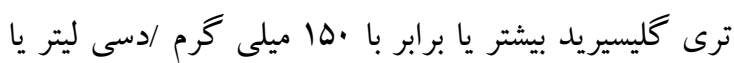
مصرف دارو براى بالابودن جربى خون، كاهش ميزان

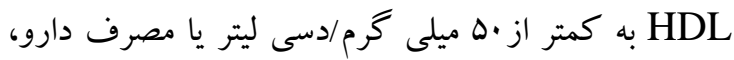
بالابودن فشار خون بر اساس بيشتر يا برابر با هA/·rاميلى مترجيوه يا مصرف دارو، افزايش ميزان قند خون ناشتا مساوى يا بيشتر از ... ميلى گرم /دسى ليتر يا مصرف دارو استفاده شد. جֶنانجه حداقل سه جزء از اجزاى سندرم متابوليكك دجار اختلال باشند، فرد مبتلا به اين سندرم

$$
\text { محسوب مى شود(1) (11). }
$$

مبتلايان به ديابت با افزايش ميز ان قند خون ناشتا، مساوى يا بيشتر از צr| ميلى گرم /دسى ليتر يا قند خون Y ساعته

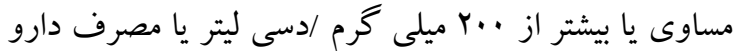
تشخيص داده شدند. جهت تشخيص ير ديابت قند خون

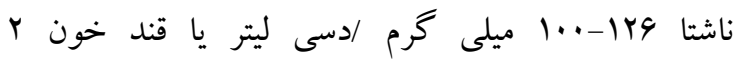

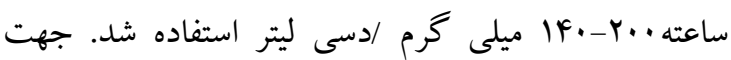
تعيين هييرتانسيون، فشار خون بر اساس بيشتر يا برابر با

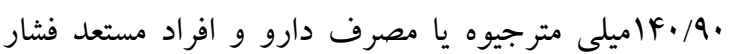




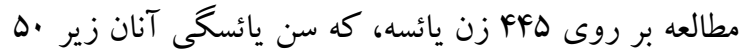
سال بود، به انجام رسيد، كه شامل 19V زن يائسه به علت برداشتن هر دو تخمدان و YVA زن يائسه به علت

$$
\text { هيستر كتو مى بود. }
$$

جدول يكك مشخصات بايه نمونه هاى يُزوهش را در مقايسه بين دو گروه يائسه جراحى نشان مى دهد. متغيرهاى سن، سن يائسگى و تعداد فرزندان زنده متولد شده در بين دو كروه اختلاف آمارى معنادار نشان مى دهد. متغيرهاى مذكور بعنوان متغيرهاى مخدوشخر در آناليزها تعديل شدند.
متغيرهاى مربوط به اختلالات متابوليك، در مقايسه دو

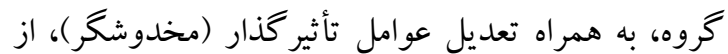
آزمون آمارى ركرسيون لجستيكك با سطح معنى دارى هـ/ • استفاده شد. يزوهش حاضر توسط كميته اخلاق يثوهشكده غدد درون ريز و متابوليسم، مورد تأييد قرار كرفته و از تمامى شركت كنندگان در بزوهش رضايت نامه كتبى آكاهانه اخذ شد.

\section{جدول ا. ويزگى هاى يايه نمونه هاى يخوهش بر اساس نوع يائسكى جراحي}

\begin{tabular}{|c|c|c|c|c|}
\hline P-value & كل نمونه ها & $\begin{array}{c}\text { زنان يائسه با برداشتن دوطرفه } \\
\text { تخمدانها } \\
\text { تحل } 19 \mathrm{~V}\end{array}$ & زنان يائسه با & متغير \\
\hline$<\cdot / \cdot+1$ & $4 \cdot / 1 \pm 9 / 1$ & $9 K / Y F \pm 9 / 9$ & $\Delta ৭ / \% \pm q / \Delta$ & سن (سال)* \\
\hline$<\cdot / \cdot 1$ & $\kappa \mu / v \pm \psi / 9$ & $F q / q \pm F / q$ & $F \psi / \cdot \pm F / q$ & سن يائسخى (سال)* \\
\hline.$/ . r$ & $\mid V / r \pm 1 \cdot /$ & $11 / 9 \pm 1 \cdot 19$ & $19 / \Delta \pm 9 / 9$ & فاصله ميان سن و سن يائسخى(سال) \\
\hline.$/ 9$ & $r \cdot / v \pm r / q$ & $r \cdot / 9 \pm \Delta / r$ & $r \cdot / v \pm r / \Lambda$ & نمايه توده بدن (كيلو گرم/متر مربع)** \\
\hline$\cdot / 4$ & $1 \cdots / \Delta \pm 11 / 4$ & $1 \cdot 1 / \cdot \pm 11 / 0$ & $1 \cdots / r \pm 11 / 4$ & دور شكم (سانتى متر)** \\
\hline$\cdot / r$ & $|Y Y / V \pm| N / q$ & $\mid r F / I \pm I V / 9$ & $|r| / 9 \pm 19 / 9$ & فشارخون سيستوليك(ميليمتر جيوه) \\
\hline \multirow[t]{2}{*}{$\cdot / r$} & $V V / F \pm 1 \cdot / 1$ & $\vee \& / \Lambda \pm 9 / \Lambda$ & $V W / \Lambda \pm 1 \cdot / r$ & فشار خون دياستوليك(ميليمتر جيوه)** \\
\hline & & & & تاريخجه بارورى \\
\hline$\cdot / 4$ & $1 / \Delta(\cdot / 9)$ & $1 / 9(\cdot / \Lambda)$ & $1 / 0(\cdot / 9)$ & سقط \\
\hline$\cdot / \Lambda$ & $1 / 1(\cdot / r)$ & $1 / 1(\cdot / r)$ & $1 / 1(\cdot / r)$ & مرده زايى \\
\hline \multirow[t]{2}{*}{.$/ \cdot 1$} & $r / \Delta(1 / 9)$ & $r / 9(1 / 9)$ & $r / r(1 / \Delta)$ & فرزندان زنده متولد شده** \\
\hline & & & & مقادير آزمايشكاهى \\
\hline$\cdot / 1$ & $119 / \Delta \pm r V / \Lambda$ & $11 Y / \Lambda \pm r q / \Delta$ & $11 N / \Lambda \pm r 4 / 9$ & LDL (ميلى گرم/دسى ليتر) \\
\hline$\cdot / r$ & $49 / 9 \pm 1 . / 9$ & $F N / Y \pm 1 \cdot / \Delta$ & $0 \cdot / 1 \pm 1 \cdot / 9$ & HDL (ميلى گرم/دسى ليتر) \\
\hline$\cdot 19$ & $101 / V \pm V / / r$ & $\mid \Delta r / \Lambda \pm V V /$. & $10 \cdot / 9 \pm V 1 / 1$ & ترى كليسريد(ميلى گرم/دسى ليتر): \\
\hline$\cdot / r$ & $199 / 1 \pm F r / 9$ & $19 Y / \Delta \pm \psi \psi / r$ & $19 / / r \pm F 1 / \Delta$ & كلسترول تام(ميلى گرم/دسى ليتر)ش* \\
\hline$\cdot / r$ & $1 \cdot V / 9 \pm \pi / V$ & $11 \cdot / 9 \pm r q / \Lambda$ & $1 \cdot \Delta / 9 \pm r q / r$ & قند خون ناشتا (ميلى گرم/دسى ليتر) )* \\
\hline$\cdot 11$ & $\mid r F / r \pm F / / \Lambda$ & $1 r q / r \pm \Delta V / q$ & $|r| \Delta \pm F Y / \Lambda$ & قند خون r ساعته (ميلى گرم/دسى ليتر) ** \\
\hline
\end{tabular}

*ميانخين

آن بود كه هيج يكك از ميانگين متغيرها، تفاوتى كه بين دو كروه معنادار باشد، نشان نمى دهد.
إفته ها 


\section{جدول r. ويزكى هاى نمونه هاى ثخوهش بر اساس نوع يائسكى جراحى يس از تعديل تعداد فرزندان، نمايه توده بدنى و فاصله بين سن و سن}

\begin{tabular}{|c|c|c|c|c|}
\hline P-value & كل نمونه ها & 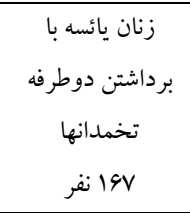 & زيستر كتومى يائسه با & متغير \\
\hline$\cdot 10$ & $1 \cdots / \wedge \pm 11 / 4$ & $1 \cdot 1 / \cdot \pm 11 / 1$ & $1 \cdots / 9 \pm 11 / r$ & دور شكم (سانتى متر) \\
\hline$\cdot / 0$ & $|Y r / 9 \pm| N / \Lambda$ & $|Y F / \cdot \pm| V / V$ & $|r| / V \pm 19 / r$ & فشارخون سيستوليك(ميليمتر جيوه)* \\
\hline \multirow[t]{2}{*}{.$/ 9$} & $V V / f \pm q / q$ & $V V / r \pm q / V$ & $V V / \Delta \pm 1 \cdot / \cdot$ & فشار خون دياستوليك(ميليمتر جيوه)** \\
\hline & & & & مقادير آزمايشكاهى \\
\hline.$/ 1$ & $\| V / V \pm r N / r$ & $11 r / v \pm F \cdot / 1$ & $1 r \cdot / \cdot \pm r q / 9$ & "LDL (ميلى گرم/دسى ليتر) \\
\hline$\cdot / 1$ & $4 q / v \pm 1 \cdot / \Delta$ & $\kappa N / A \pm 1 \cdot / r$ & $0 \cdot / Y \pm 1 \cdot / 9$ & HDL (ميلى گرم/دسى ليتر) \\
\hline$\cdot / 4$ & $\mid Q F / Y \pm V F / F$ & $10 V / q \pm V q / 1$ & $|\Delta r / \cdot \pm V| / V$ & ترى گليسريد(ميلى گرم/دسى ليتر) ** \\
\hline$\cdot / r$ & $19 V / Y \pm F Y / \Delta$ & $191 / 1 \pm F F / V$ & $r \cdot \cdot / \cdot \pm r \mid / r$ & كلسترول تام(ميلى گرم/دسى ليتر) ** \\
\hline$\cdot / 0$ & $1.9 / 9 \pm \mu 1 / 0$ & $1.9 / 1 \pm r \Delta / 9$ & $1 \cdot \Delta / 9 \pm Y N / 9$ & قند خون ناشتا (ميلى خرم/دسى ليتر) ** \\
\hline$\cdot / f$ & $\mid r \Delta / \backslash \pm F \wedge / r$ & $1 r q / \Delta \pm \Delta q / 9$ & $\mid r Y / V \pm F Y /$ & قند خون Y ساعته (ميلى گرم/دسى ليتر) \%* \\
\hline
\end{tabular}

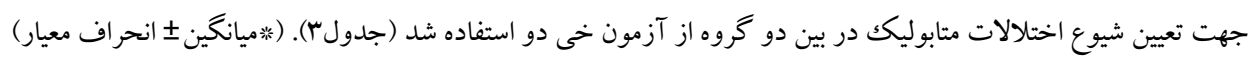

\begin{tabular}{|c|c|c|c|c|}
\hline P-value & كل نعدونه هاد & زونان يائسه با برداشتن & تيستر كتان يائسه با & متغير \\
\hline$\cdot / \Delta$ & $r \mid G(F / / \Delta)$ & $\operatorname{Ar}(F q / 1)$ & $\operatorname{IrF}(F V / Y)$ & هيير تانسيون \\
\hline $.1 \cdot 1$ & $\operatorname{lIV}(r g / T)$ & $\Delta r^{\prime}(r / N)$ & $G Y(Y \mu / \cdot)$ & ير هيير تانسيون \\
\hline$\cdot / 1$ & $\operatorname{IFF}(r Y / r)$ & $q \cdot(r \Delta / Q)$ & $\Lambda F(r \cdot / r)$ & ديابت \\
\hline \multirow[t]{2}{*}{$\cdot / \Delta$} & $\Lambda F(19 / \Lambda)$ & $r q(I V / F)$ & $\Delta \Delta(19 / \wedge)$ & يرديابت \\
\hline & & & & سندرم متابوليك و اجزاى آن \\
\hline$\cdot / r$ & $r \cdot F(\xi \Lambda / r)$ & $119(V 1 / \%)$ & $1 \wedge \Delta(94 / \Delta)$ & سندرم متابوليكك \\
\hline .1 .9 & $r \Delta Q(\Delta \Lambda / Y)$ & $1 . \Delta(9 Y / 9)$ & $\mid \Delta F(\Delta \Delta / F)$ & فشار خون افزايش يافته \\
\hline$\cdot / 4$ & HIध (VI/•) & $11 \wedge(\vee \cdot 19)$ & $19 \wedge(V 1 / T)$ & كاهش HDL \\
\hline$\cdot / \pi$ & $r \Lambda \cdot(\& T / q)$ & $1 \cdot r(\xi 1 / V)$ & $\operatorname{IVV(\& T/V)}$ & تريخليسيريد افز ايش يافته \\
\hline$\cdot / T$ & TET(VV/I) & $|r|(V N / F)$ & $r \mid r(V G / T)$ & دور شكم افزايش يافته \\
\hline$\cdot / \pi$ & $r \cdot q(F V / \cdot)$ & $N r(r q / 1)$ & $\mid r V(F \varepsilon \mid \cdot)$ & قند خون ناشتا افزايش يافته \\
\hline
\end{tabular}

\section{جدول r. شيوع اختلالات متابوليكك در ميان نمونه هاى بروهش بر اساس نوع يائسكى جراح}

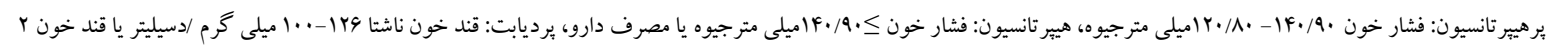

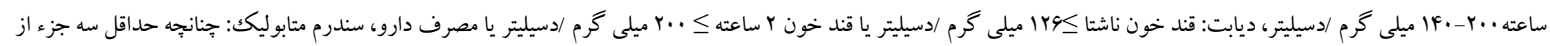

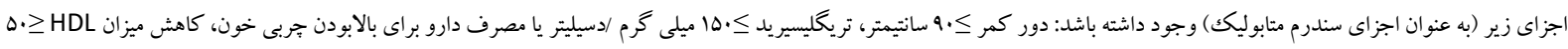

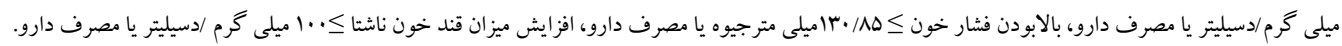


نظر آمارى معنادار نبودند. تنها متغير بيرهيبرتانسيون بين دو كروه اختلاف معنادار آمارى داشت به اين شكل كه ميزان شيوع اين متغير در كروه يائسه جراحى با برداشتن هر دو احو إن تخمدان نسبت به گروه يائسه جراحى بدليل هيستر كتومى از فراوانى بيشترى برخودار بود ( P-value>0.05). آزمون آمارى ركرسيون لجستيك، براى مقايسه شيوع اختلالات متابوليك و سندرم متابوليك و اجزاى آن، در بين دو گروه مطالعه با تعديل متغيرهاى مخدوشخر استفاده

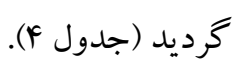

براين اساس ميزان شيوع سندرم متابوليك در زنان يائسه به روش اووفوركتومى دوطرفه(/T/K) و در زنان يائسه به روش هيستر كتومى.94/0 بود ، هر جند كه اين اختلاف از لحاظ آمارى معنادار نبود. تنها شيوع HDL كاهش يافته و تريخليسيريد افزايش يافته به عنوان دو جزء از اجزاى سندرم

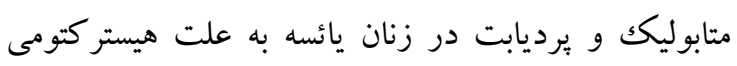
بيشتر از زنان اووفوركتومى دوطرفه بود و بقيه متغيرهاى تشكيل دهنده اختلالات متابوليكك به عكس در زنان يائسه به علت اووفور كتومى دوطرفه بيشتر بود، اما اين اختلافات از

جدول ع. بر آورد نسبت شانس اختلالات متابوليك در ميان نمونه هاى يزوهش بر اساس نوع يائسكى جراحى

\begin{tabular}{|c|c|c|}
\hline P-value & OR $(95 \%$ CI $)$ & متغير \\
\hline$\cdot / 4$ & $\cdot / \Lambda(\cdot \mid \Delta-1 / T \Lambda)$ & هيير تانسيون \\
\hline$\cdot 1 \cdot r$ & $1 / 9 \Delta(1 / \cdot V-r / \Delta \Lambda)$ & ير هيير تانسيون \\
\hline$\cdot / V$ & $1 / 1 \cdot(\cdot / V-1 / V 9)$ & ديابت \\
\hline \multirow[t]{2}{*}{$\cdot 11$} & $\cdot / 9 F(\cdot / \Delta-1 / 9 \Lambda)$ & يرديابت \\
\hline & & سندرم متابوليك و اجزاى آن \\
\hline$\cdot 19$ & $1 / 14(\cdot / \mathrm{N})-1 / \mathrm{A} \cdot)$ & سندرم متابوليكك \\
\hline$\cdot / 4$ & $1 / T(\cdot / V \vee-1 / \Lambda \varepsilon)$ & فشار خون افزايش يافته \\
\hline.$/ 9 V$ & $1 / \cdot(\cdot / 9 q-1 / \Delta q)$ & كاهش HDL \\
\hline$\cdot / 4$ & $\cdot / \Lambda T(\cdot / \Delta F-1 / T \varphi)$ & تريگليسير يد افزايش يافته \\
\hline$\cdot 19$ & $\cdot / 99(\cdot / 0 F-1 / 99)$ & دور شكم افزايش يافته \\
\hline$\cdot / V$ & $\cdot / 9 r(\cdot|9|-1 / 4)$ & قند خون ناشتا افزايش يافته \\
\hline
\end{tabular}

CI

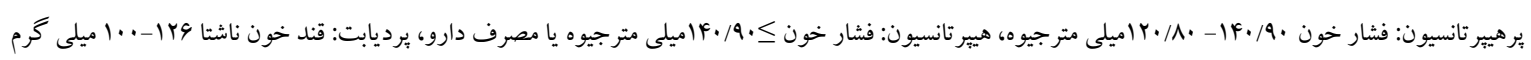

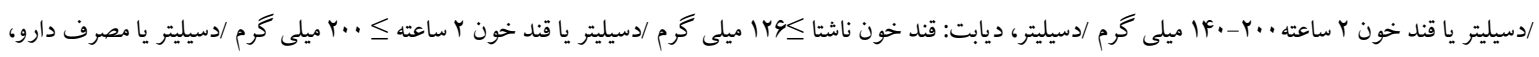

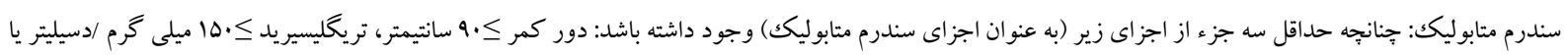

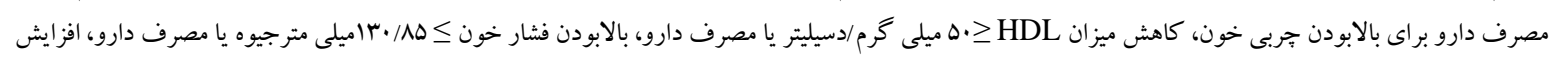

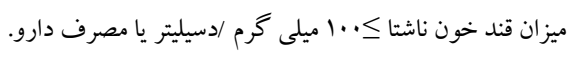

P-value<0.05 , يائسه به روش هيستر كتومى بود $. \mathrm{OR}=1.95,95 \% \mathrm{CI}(1.07,3.58)$

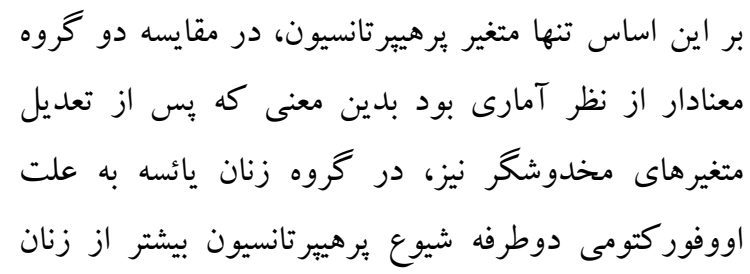

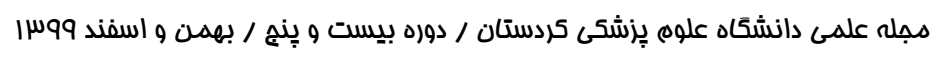


دارند(ب/). در راستاى نتايج مطالعه حاضر، نتايج يزوهشى

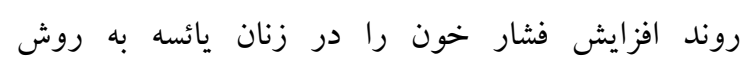

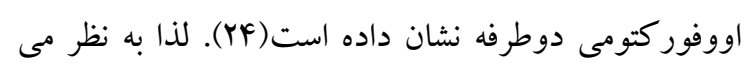

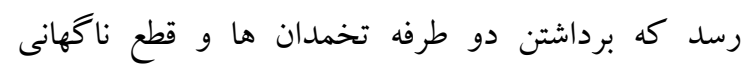

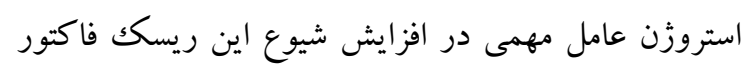

$$
\text { مهم بيمارى هاى قلبى عروقى باشد. }
$$

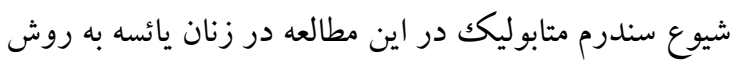

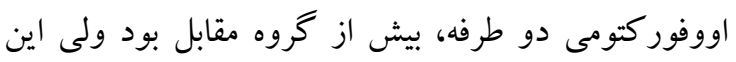

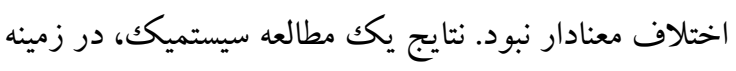

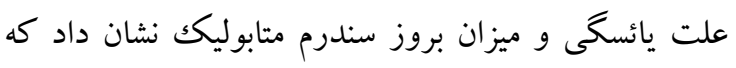

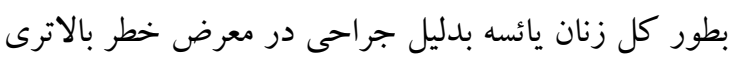

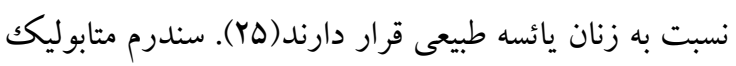

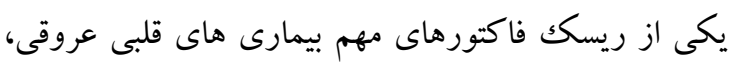

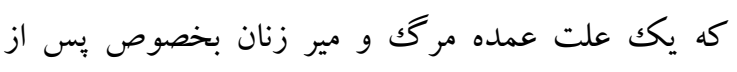

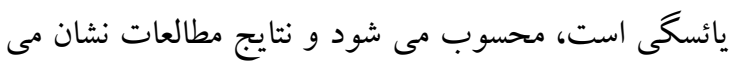

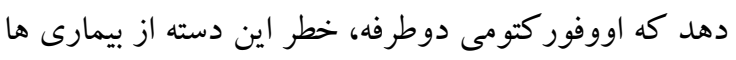

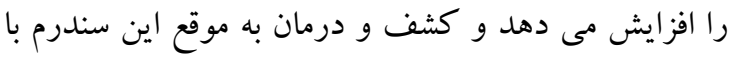

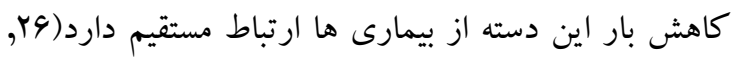

نتايج مطالعه حاضر نشان داد كه اكثر ريسك فاكتورهاى قلبى عروقى در زنان يائسه به روش اووفور كتومى از شيوع

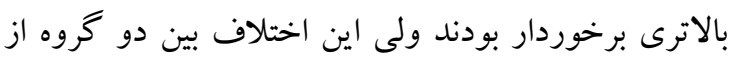

$$
\text { نظر آمارى معنادار نبود. }
$$

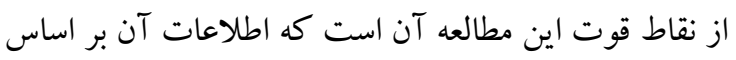
يكك مطالعه مبتنى بر جمعيت استخراج شده است، بنابر اين

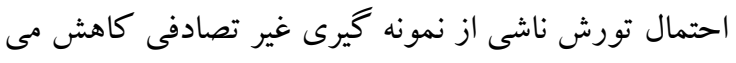

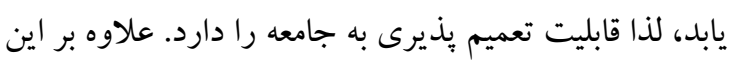

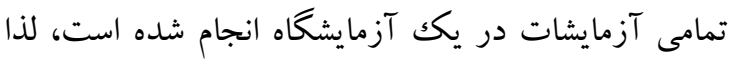

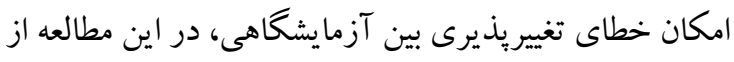

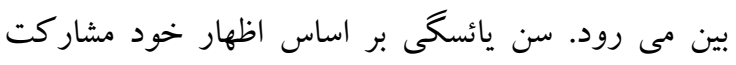

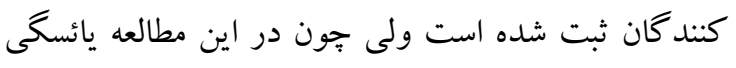

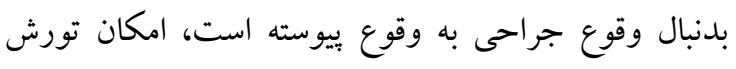
ناشى از يادآورى در اين مطالعه به حداقل مى رسد. علاوه بر بر بئه
نتايج ئزوهش حاضر نشان داد كه از بين اختلالات

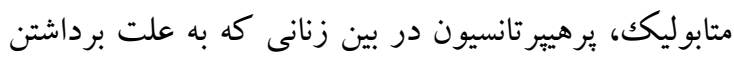

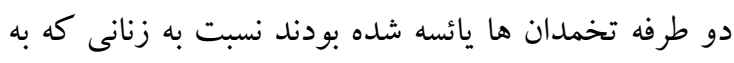

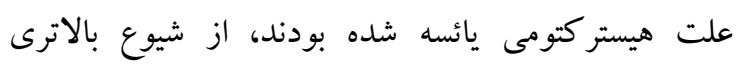

$$
\text { برخوردار بود. }
$$

يافته هاى يثزوهش حاضر نشان داد كه ميانگين سن و سن بن

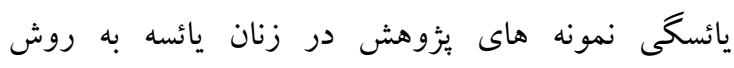

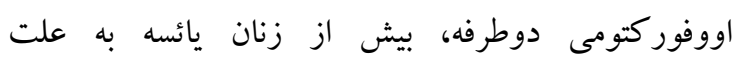

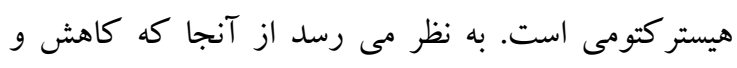

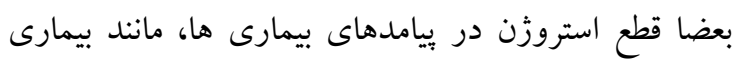
هاى قلبى عروقى دخيل است(IF) لذا در صورت امكان بايد، حفظ تخمدان ها يا دست كم يكى از آنها تان آنا سنين بالاتر انجام شود، تا زنان از مزاياى هورمون هاى جاى جنسى تال

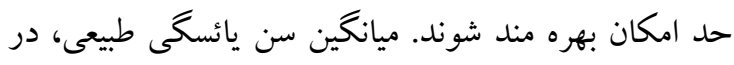

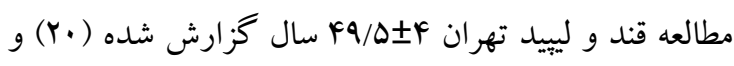

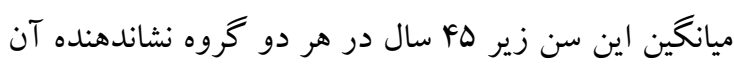

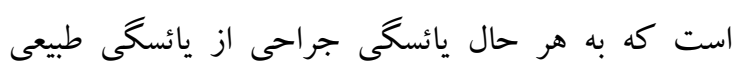
زودتر اتفاق مى افتد. اين موضوع در مطالعات ديخر نيز

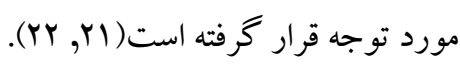

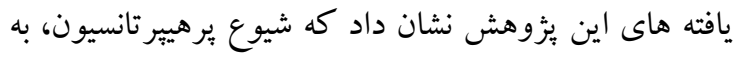

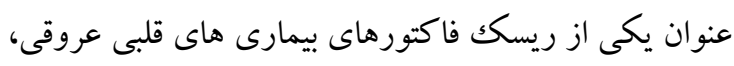
در زنان يائسه به روش اوفور كتومى دو طرفه، بيش از زنان يائسه به روش هيستر كتومى بود و اين اختلاف قبل و بعد از تعديل متغيرهاى مخدوشخر، از نظر آمارى معنادار بود. نتايج

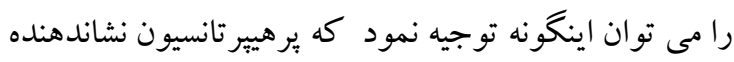
اين است كه فرد در معرض خطر فشارخون بالا قرار دارد و فشار خون خود يكى از ريسك فاكتورهاى مهم بيمارى هاى غير واگير، مانند بيمارى هاى قلبى عروقى و كليه است. رئ

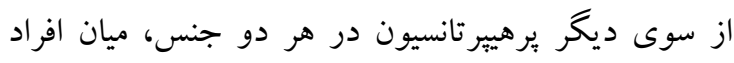

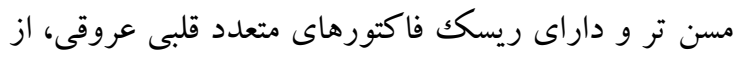
شيوع بالاترى برخوردار است و افزايش سن و نمايه توده

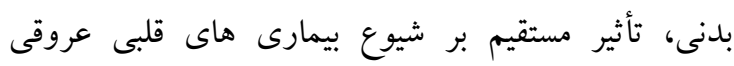




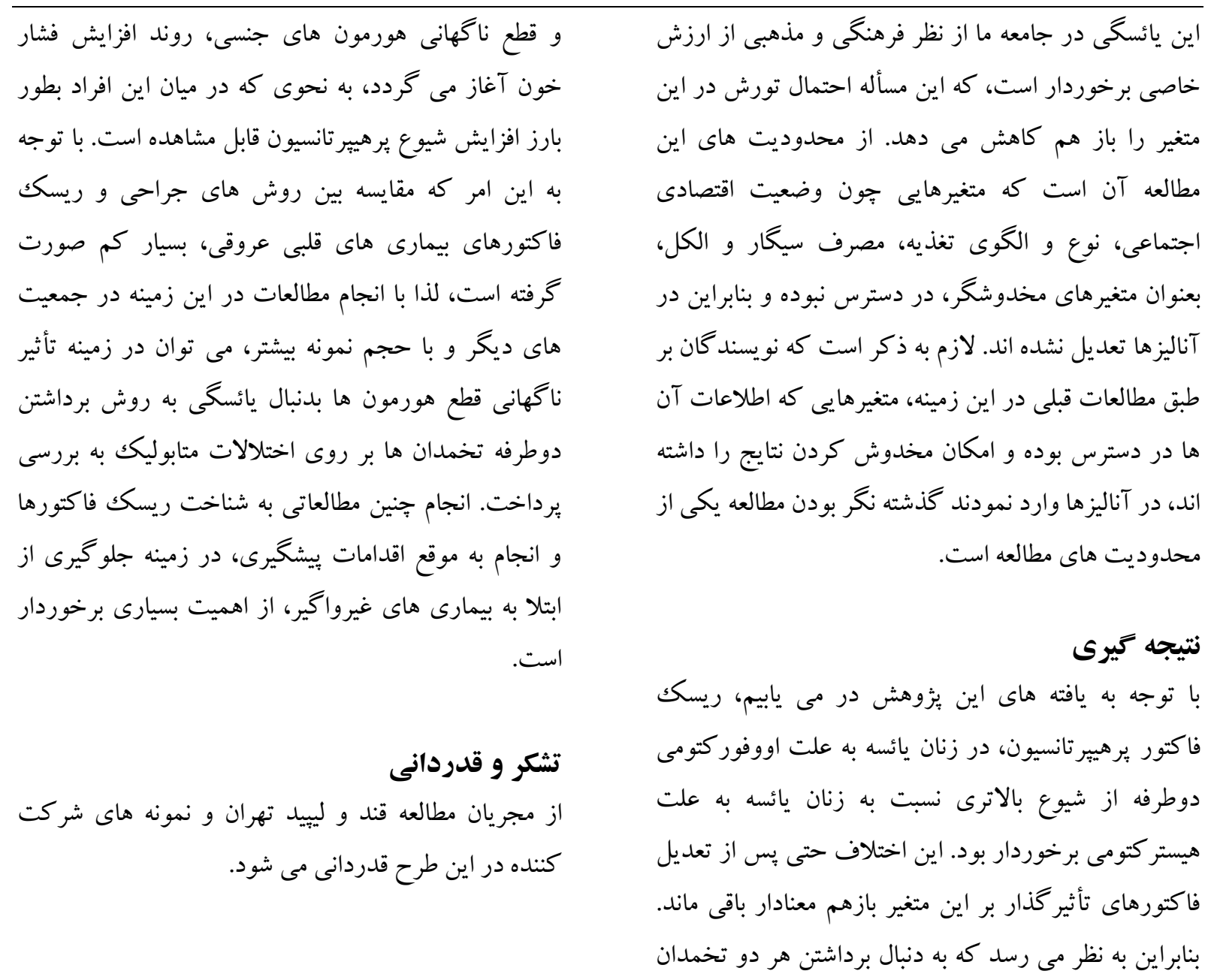

\section{منابع}

1.Santoro, N. and J.F. Randolph, Reproductive hormones and the menopause transition. Obstetrics and Gynecology Clinics, 2011. 38(3): p. 455-466.

2.Baber, R.J., N. Panay, and A. Fenton, 2016 IMS Recommendations on women's midlife health and menopause hormone therapy. Climacteric, 2016. 19(2): p. 109-50.

3.Reaven, G.M., Role of insulin resistance in human disease. Diabetes, 1988. 37(12): p. 15951607.

4.Ford, E.S., W.H. Giles, and W.H. Dietz, Prevalence of the metabolic syndrome among US adults: findings from the third National Health and Nutrition Examination Survey. Jama, 2002. 287(3): p. 356-9.

5.Beltrán-Sánchez, H., et al., Prevalence and trends of metabolic syndrome in the adult US population, 1999-2010. Journal of the American College of Cardiology, 2013. 62(8): p. 697703.

6.Vermeulen, R.F.M., et al., Impact of risk-reducing salpingo-oophorectomy in premenopausal women. Climacteric, 2017. 20(3): p. 212-221.

7.Farahmand, M., et al., Adverse Cardiometabolic Effect in Bilateral/Unilateral Oophorectomy Versus Natural Menopause: Results of Over a Decade Follow-up Among Iranian Women. Archives of Iranian Medicine (AIM), 2017. 20(12). 
8.Giugliano, D. and K. Esposito, The metabolic syndrome: time for a critical appraisal: joint statement from the American Diabetes Association and the European Association for the Study of Diabetes: response to Kahn et al. Diabetes care, 2006. 29(1): p. 175-176.

9.Farahmand, M., et al., Does metabolic syndrome or its components differ in naturally and surgically menopausal women? Climacteric, 2014. 17(4): p. 348-355.

10.Farahmand, M., et al., Surgical menopause versus natural menopause and cardio-metabolic disturbances: A 12-year population-based cohort study. Journal of endocrinological investigation, 2015. 38(7): 761-767.

11.Kilic, S., et al., Effect of non-oral estrogen on risk markers for metabolic syndrome in early surgically menopausal women. Climacteric, 2010. 13(1): p. 55-62.

12.Zachariasen, R.D., Oral manifestations of bulimia nervosa. Women Health, 1995. (4)22: p. 67-76.

13.Sitruk-Ware, R. and P. Ibarra de Palacios, Oestrogen replacement therapy and cardiovascular disease in post-menopausal women. A review. Maturitas, 1989. 11(4): p. 25974.

14.Farahmand, M., et al., Association between duration of endogenous estrogen exposure and cardiovascular outcomes: A population-based cohort study. Life sciences, 2019. 221: p. 335340 .

15.Coyoy, A., C. Guerra-Araiza, and I. Camacho-Arroyo, Metabolism regulation by estrogens and their receptors in the central nervous system before and after menopause. Hormone and Metabolic Research, 2016. 48(08): p. 489-496.

16.Morselli, E., et al., The effects of oestrogens and their receptors on cardiometabolic health. Nature Reviews Endocrinology, 2017. 13(6): p. 352.

17.Azizi, F., et al., Prevention of non-communicable disease in a population in nutrition transition: Tehran Lipid and Glucose Study phase II. Trials, 2009. 10(1): p. 5.

18.Alberti, K., et al., Harmonizing the metabolic syndrome: a joint interim statement of the international diabetes federation task force on epidemiology and prevention; national heart, lung, and blood institute; American heart association; world heart federation; international atherosclerosis society; and international association for the study of obesity. Circulation, 2009. 120(16): p. 1640-1645.

19.Khalili, D., et al., Outcomes of a longitudinal population-based Cohort Study and pragmatic community trial: Findings from 20 years of the Tehran Lipid and Glucose Study. International journal of endocrinology and metabolism, 2018. 16(4 Suppl).

20.Farahmand, M., et al., Factors associated with menopausal age in I ranian women: T ehran L ipid and G lucose S tudy. Journal of Obstetrics and Gynaecology Research, 2013. 39(4): p. 836-841.

21.Farahmand, M., et al., Occurrence of metabolic syndrome and components in postmenopausal women with natural or surgical menopause. 2012.

22.Tuna, V., et al., Variations in blood lipid profile, thrombotic system, arterial elasticity and psychosexual parameters in the cases of surgical and natural menopause. Australian and New Zealand journal of obstetrics and gynaecology, 2010. 50(2): p. 194-199.

23.Hadaegh, F., et al., Prehypertension tsunami: a decade follow-up of an Iranian adult population. PloS one, 2015. 10(10) p. e0139412.

24.Dorum, A., et al., Bilateral oophorectomy before 50 years of age is significantly associated with the metabolic syndrome and Framingham risk score: a controlled, population-based study (HUNT-2). Gynecol Oncol, 2008. 109(3): p. 377-83. 
25.Pu, D., et al., Metabolic syndrome in menopause and associated factors: a meta-analysis. Climacteric, 2017. 20(6): p. 583-591.

26.Dørum, A., et al., Bilateral oophorectomy before 50 years of age is significantly associated with the metabolic syndrome and Framingham risk score: a controlled, population-based study (HUNT-2). Gynecologic oncology, 2008. 109(3): p. 377-383.

27.Das, N., V.J. Kay, and T.A. Mahmood, Current knowledge of risks and benefits of prophylactic oophorectomy at hysterectomy for benign disease in United Kingdom and Republic of Ireland. European Journal of Obstetrics \& Gynecology and Reproductive Biology, 2003. 109(1): p. 76-79. 